\title{
HUBUNGAN PEMBERIAN REWARD DENGAN MOTIVASI KERJA PERAWAT DI RUANG RAWAT INAP RUMAH SAKIT JIH YOGYAKARTA
}

\author{
Widuri $^{1}$, Maryadi $^{2}$, Yuli Vianasih ${ }^{3}$ \\ 1,3Program Studi S1 IImu Keperawatan STIKES Guna Bangsa Yogyakarta \\ ${ }^{2}$ Rumah Sakit Umum Daerah Prambanan Yogyakarta \\ e-mail: ${ }^{1}$ widuri@gunabangsa.ac.id
}

\begin{abstract}
Background: The award is very important to increase the productive activity, it is expected the award given to an individual can improve employee motivation for work valued thus improving the performance of employees and to motivate the work of nurses.

Objective: To determine the relationship of reward and motivation of nurses in the inpatient hospital JIH Yogyakarta.

Method: Types of non-experimental research design with descriptive analytic and quantitative methods, and using cross sectional approach. Sampling technique used is total sampling (87 nurses). The instruments used were questionnaires about reward and motivation. This research was conducted in inpatient hospital JIH Yogyakarta from January to February 2015.

Result: Spearman's test results show that the significance value of $0.447(>0.05)$ showed that no significant relationship between the two variables at a very low level of closeness $(r$ 0.083).
\end{abstract}

Conclusion: There was no significant relationship between reward and motivation of nurses in patient wards of hospitals $\mathrm{JIH}$ Yogyakarta in 2015.

Keywords: Reward, Work motivation of nurse

\section{LATAR BELAKANG}

Kompetisi antar Rumah Sakit pada era global seperti sekarang ini semakin ketat, terlihat dari jumlah pelayanan kesehatan yang semakin banyak berdiri di kota atau di daerah. Bukan hanya Rumah Sakit pemerintah, tetapi banyak berkembang Rumah Sakit swasta, Klinik, Rumah Bersalin dan yang lain. Sehingga menimbulkan persaingan bagi Rumah Sakit untuk mempertahankan, meningkat- kan kualitas pelayanan dan eksistensinya, terutama bagi Rumah Sakit swasta. Salah satu cara untuk meningkatkan kualitas pelayanan Rumah Sakit dapat ditempuh dengan meningkatkan kemampuan sumber daya manusia (SDM), karena SDM merupakan modal dan kekayaan yang penting dari setiap kegiatan manusia. ${ }^{1}$

SDM mempunyai peranan utama dalam setiap kegiatan perusahaan terutama yang bergerak dibidang pemberi jasa pelayanan kesehatan.Salah satu SDM 
yang penting dalam pelayanan suatu Rumah Sakit adalah perawat, karena perawat merupakan SDM yang paling dominan diantara SDM yang ada di Rumah Sakit.

Akan tetapi fenomena yang sering terjadi adalah manakala organisasi suatu Rumah Sakit yang sudah baik dapat menjadi rusak, baik secara langsung maupun tidak langsung oleh berbagai perilaku karyawan.Berbagai macam motivasi perawat untuk keluar dari pekerjaan atau keinginan pindah (turn over/intensions to leave) adalah karena berbagai macam sebab diantaranya yaitu mendapatkan pekerjaan yang lebih baik, balas jasa yang terlalu rendah, kesempatan promosi yang tidak ada, serta perlakuan yang kurang adil. Sehingga dengan adanya fenomena tersebut setiap Rumah Sakit harus selalu bekerja keras bagaimana caranya agar perawat mempunyai motivasi yang tinggi dalam bekerja. $^{2}$

Motivasi terbentuk dari sikap (atittude) karyawan dalam menghadapi situasi kerja di perusahaan (situasion), motivasi merupakan kondisi atau energi yang menggerakkan diri karyawan yang terarah atau petunjuk untuk mencapai tujuan organisasi perusahaan. Sikap mental karyawan yang pro dan positif terhadap situasi kerja itulah yang memperkuat motivasi kerjanya untuk mencapai kinerja yang maksimal. ${ }^{3}$

Reward di dalam organisasi
bertujuan untuk menarik dan mempertahankan SDM, karena organisasi memerlukannya untuk mencapai sasaransasarannya sebagai timbal balik dari jasa karyawan untuk meningkatkan prestasi kerja. Dalam konteks MSDMmanajemen reward tidak semata hanya pada pemberian reward misalnya upah, gaji, bonus, komisi dan pembagian laba yang biasa disebut reward (finansial). Namun hal yang tak kalah penting adalah reward (non finansial) yang merupakan pemuas kebutuhan psikologis karyawan seperti pekerjaan yang menantang, prestasi, pengakuan, otonomi, kesempatan mengembangkan diri, dan pemberian kesempatan dalam proses pengambilan keputusan. ${ }^{4}$
Penghargaan sangat penting untuk meningkatkan kegiatan yang produktif dan menggurangi kegiatan yang negatif dan diharapkan adanya penghargaan yang diberikan kepada individu dapat meningkatkan motivasi karyawan karena pekerjaan dihargai sehingga meningkatkan kinerja karyawan. ${ }^{5}$

Menurut data dari keperawatan Rumah Sakit JIH, didapatkan bahwa sejak berdirinya Rumah Sakit tersebut terdapat angka turn over perawat yang cukup tinggi. Data yang didapat oleh peneliti dari bagian keperawatan Rumah Sakit JIH menunjukkan tingkat turn over perawat pada tahun 2011 dengan jumlah perawat 160 orang, jumlah perawat yang resign sebanyak 30 orang (18,75\%). Pada tahun 2012 dengan jumlah perawat sebanyak 189 orang, jumlah perawat yang resign sebanyak 34 orang $(17,98 \%)$, dan pada tahun 2013 jumlah perawat 207 orang, dengan jumlah perawat yang resign sebanyak 27 orang (13,04\%). Hal ini cukup menjadi masalah yang penting di dalam MSDM terutama dibagian keperawatan, sehingga masalah tersebut perlu dicari penyebab utama tingginya turn over di Rumah Sakit JIH.

Dari hasil interview oleh manager keperawatan selama tahun 2013, tercatat 9 perawat $(33,33 \%)$ keluar dari pekerjaan dengan alasan karena mendapat tawaran pekerjaan di Rumah Sakit lain dengan reward yang lebih besar, 6 perawat $(22,22 \%)$ merasa tidak cocok dengan atasan, 8 perawat $(29,6 \%)$ merasa pekerjaan sebagai perawat di Rumah Sakit $\mathrm{JIH}$ terlalu banyak, dan 4 perawat $(14,8 \%)$ mengatakan bahwa mereka mengundurkan diri karena mengikuti suami.

Meskipun Rumah Sakit JIH telah memberikan beberapa reward sejak tahun 2010 berupa pembagian jasa performa setiap bulan, jasa produksi, serta insentif jasa pelayanan yang dibagikan tiap 3 bulan sekali, tetapi hal tersebut dinilai masih kurang. Masalah reward (insentif jasa pelayanan, jasa performa dan jasa produksi) sering dikeluhkan oleh perawat dengan masa kerja yang sudah cukup lama, dimana mereka merasa bahwa imbalan yang diterima selama ini tidak berbeda jauh dengan yang diberikan oleh 
perawat baru. Sehingga secara langsung atau tidak langsung pemberian rewardakan mempengaruhi motivasi kerja perawat yang ada di Rumah Sakit JIH.

Berdasarkan latar belakang tersebut, maka penulis tertarik untuk melakukan penelitian tentang sejauh mana "Hubungan Pemberian Reward dengan Motivasi Kerja Perawat Di Ruang Rawat Inap Rumah Sakit JIH Yogyakarta".

\section{Tujuan Umum}

Mengetahui hubungan pemberian reward dengan motivasi kerja perawat di ruang rawat inap Rumah Sakit $\mathrm{JIH}$ Yogyakarta.

\section{METODE PENELITIAN}

Penelitian ini merupakan jenis penelitian non-eksperimen dengan desain diskriptif analitik dan metode kuantitatif, serta menggunakan pendekatan waktu cross sectional. Penelitian dilakukan pada bulan Januari sampai dengan bulan Februari 2015.

Populasi dalam penelitian ini adalah Perawat pelaksana di ruang rawat inap Rumah Sakit JIH Yogyakarta yang terdiri dari ruang Orchid, Jasmin Utara, Jasmin Timur, Pediatric, Kamar Bayi, Gardenia, Camelia dan Bougenvil dengan jumlah 87 Perawat kecuali perawat ICU/ICCU.Teknik yang di- gunakan yaitu dengan cara sampling jenuh atau sensus/total sampling.

Kuesioner dalam penelitian ini terdiri dari 2 bagian, kuesioner pertama merupakan kuesioner mengenai pemberian reward dan kuesioner kedua merupakan kuesioner mengenai motivasi kerja perawat.Uji validitas dan reliabilitastelah dilakukan oleh peneliti di Rumah Sakit Islam PDHI Yogyakarta pada tanggal 10 sampai tanggal 12 Januari 2015.

\section{HASIL DAN PEMBAHASAN}

1. Karakteristik Responden

Tabel 1.

Distribusi Frekuensi Responden berdasar Karakteristik di Ruang Rawat Inap RS JIH Yogyakarta $(n=87)$

\begin{tabular}{|c|c|c|}
\hline Karakteristik & $\mathbf{F}$ & $\%$ \\
\hline \multicolumn{3}{|l|}{ Jenis kelamin } \\
\hline Laki-laki & 5 & 5,7 \\
\hline Perempuan & 82 & 94,2 \\
\hline Total & 87 & $100 \%$ \\
\hline \multicolumn{3}{|l|}{-ama kerja } \\
\hline$<1$ tahun & 10 & 11,5 \\
\hline 1-5 tahun & 71 & 81,6 \\
\hline$>5$ tahun & 6 & 6,9 \\
\hline Total & 87 & $100 \%$ \\
\hline \multicolumn{3}{|l|}{ Usia } \\
\hline$<25$ tahun & 22 & 25,3 \\
\hline 25-30 tahun & 55 & 63,2 \\
\hline$>30$ tahun & 10 & 11,5 \\
\hline Total & 87 & $100 \%$ \\
\hline \multicolumn{3}{|l|}{ Pendidikan } \\
\hline D3 & 76 & 87,4 \\
\hline SI & 11 & 12,6 \\
\hline Total & 87 & $100 \%$ \\
\hline \multicolumn{3}{|l|}{ Status perkawinan } \\
\hline Menikah & 61 & 71,1 \\
\hline Belum menikah & 25 & 28,7 \\
\hline Lain-lain & 1 & 1,1 \\
\hline Total & 87 & $100 \%$ \\
\hline
\end{tabular}

Berdasarkan tabel 1 diatas dapat diketahui bahwa karakteristik responden berdasarkan jenis kelamin didapatkan responden terbanyak adalah perempuan yaitu sebanyak $82(94,2 \%)$. Karakteristik responden berdasarkan lama kerja didapatkan sebanyak $71 \quad(81,6 \%)$ responden dengan lama kerja 1-5 tahun. Karakteristik responden berdasarkan usia, didapatkan 55 (63,2\%). Karakteristik responden berdasarkan tingkat pendidikan, didapatkan mayoritas responden berpendidikan D3 dengan jumlah sebesar 76 (87,4\%). Karakteristik responden berdasarkan status perkawinan, didapatkan mayoritas responden berstatus sudah menikah yaitu sebanyak $61(71,1 \%)$. 
2. Pemberian Reward Perawat di Ruang Rawat Inap RS JIH Yogyakarta

Tabel 2.

Tingkat Pemberian Reward Perawat di Ruang Rawat Inap RS JIH Yogyakarta 2015 $(\mathbf{n}=\mathbf{8 7})$

\begin{tabular}{|c|c|c|c|c|}
\hline No & Indikator & & $\mathbf{F}$ & $\%$ \\
\hline \multirow[t]{3}{*}{1} & \multirow{3}{*}{$\begin{array}{l}\text { Uang } \\
\text { bonus, } \\
\text { pensiun) }\end{array}$} & Tinggi & 1 & 1,1 \\
\hline & & Sedang & 51 & 58,6 \\
\hline & & Rendah & 35 & 40,2 \\
\hline \multirow[t]{4}{*}{2} & \multirow{3}{*}{$\begin{array}{l}\text { Jaminan Sosial } \\
\text { (jaminan } \\
\text { kesehatan, cuti, } \\
\text { pendidikan dan } \\
\text { pelatihan) }\end{array}$} & Tinggi & 25 & 28,7 \\
\hline & & Sedang & 53 & 60,9 \\
\hline & & Rendah & 9 & 10,3 \\
\hline & Total $(n)$ & 87 & & $100 \%$ \\
\hline
\end{tabular}

Pada tabel 2 terlihat bahwa mayoritas responden atau sebesar $70,1 \%$ responden perawat dalam penelitian ini menganggap bahwa reward yang diberikan adalah sedang. Meskipun demikian, terdapat $18,4 \%$ responden yang menganggap reward yang diberikan masih rendah.

Adapun ditinjau berdasarkan indikator-indikator reward, penilaian responden perawat terhadap indikator uang dan jaminan sosial dapat dilihat pada tabel 3 berikut.

Tabel 3.

Tingkat Pemberian Reward Perawat di Ruang Rawat Inap RS JIH Yogyakarta 2015 Berdasarkan Indikatornya $(\mathbf{n}=\mathbf{8 7})$

\begin{tabular}{cccc}
\hline No & $\begin{array}{c}\text { Tingkat Pemberian } \\
\text { Reward }\end{array}$ & F & $\%$ \\
\hline 1 & Tinggi & 10 & 11,5 \\
2 & Sedang & 61 & 70,1 \\
3 & Rendah & 16 & 18,4 \\
\hline \multicolumn{2}{c}{ Total $(\mathrm{n})$} & 87 & $100 \%$ \\
\hline
\end{tabular}

Berdasarkan tabel 3 dapat diketahui bahwa ditinjau dari indikator uang, sebagian besar atau sebesar 58,6\% responden menganggap bahwa pemberian reward uang adalah sedang. Namun, sebanyak $40,2 \%$ responden menganggap bahwa pemberian reward uang kepada mereka adalah rendah. Ditinjau dari indikator jaminan sosial, sebagian besar atau sebesar $60,9 \%$ responden perawat menganggap bahwa pemberian reward jaminan sosial adalah sedang. Hanya ditemukan $10,3 \%$ responden perawat saja yang menganggap bahwa pemberian reward jaminan sosial adalah rendah.

Indikator pemberian reward uang yang memperoleh penilaian terburuk di mana 40,2\% responden menganggap bahwa pemberian reward uang kepada mereka adalah rendah pada penelitian ini sesuai dengan kajian tenaga kerja medis di Indonesia. Gaji perawat di Indonesia tergolong rendah karena distribusi perawat yang tidak merata di Indonesia. ${ }^{6}$ Pemerintah sampai saat ini belum mengeluarkan regulasi yang mengatur kelayakan gaji perawat sehingga banyak rumah sakit memberlakukan standar UMR (Upah Minimum Regional) untuk menggaji perawat meskipun standar pendidikan mereka cukup tinggi.

Adapun indikator pemberian reward jaminan sosial yang mendapatkan hasil lebih baik di mana 10,9\% responden perawat saja yang menganggap bahwa pemberian reward jaminan sosial adalah rendah. Pada penelitian ini dapat dilihat bahwa pemberian reward jaminan sosial mendapatkan penilaian yang lebih baik ketimbang indikator reward uang karena pemerintah memiliki peraturan yang jelas terkait standar minimal jaminan sosial yang dituangkan dalam bentuk Peraturan Pemerintah tentang Penyelenggaraan Jaminan Sosial Tenaga Kerja (Peraturan Pemerintah No. 14 Tahun 1993).

3. Motivasi Kerja Perawat di Ruang Rawat Inap RS JIH Yogyakarta

Tabel 4.

Tingkat Motivasi Kerja Perawat di Ruang Rawat Inap RS JIH Yogyakarta 2015 (n= 87)

\begin{tabular}{clcc}
\hline No & Motivasi Kerja & F & $\%$ \\
\hline 1 & Tinggi & 41 & 47,1 \\
2 & Sedang & 46 & 52,9 \\
\hline \multicolumn{2}{c}{ Total $(\mathrm{n})$} & 87 & $100 \%$ \\
\hline
\end{tabular}

Pada tabel 4 terlihat bahwa mayoritas responden atau sebesar 52,9\% responden perawat dalam penelitian ini diketahui memiliki motivasi kerja yang sedang dan sisanya $47,1 \%$ diketahui memiliki motivasi kerja yang tinggi.

Adapun ditinjau berdasarkan indikator-indikator motivasi kerjamotivasi kerja responden perawat berdasarkan 
indikator tanggung jawab, prestasi dan kemajuan dapat dilihat pada tabel 5 berikut.

Tabel 5.

Motivasi Kerja Perawat di ruang Rawat Inap RS JIH Yogyakarta 2015 Berdasarkan Indikatornya $(\mathbf{n}=\mathbf{8 7})$

\begin{tabular}{crrrrlll}
\hline \multirow{2}{*}{ Reward } & \multicolumn{3}{c}{ Motivasi Kerja } & & \multirow{2}{*}{ Total } \\
\cline { 2 - 5 } & \multicolumn{2}{c}{ Tinggi } & \multicolumn{2}{c}{ Sedang } & & \multicolumn{2}{c}{} \\
\cline { 2 - 6 } & $\mathrm{F}$ & $\%$ & $\mathrm{~F}$ & $\%$ & $\mathrm{~F}$ & $\%$ \\
\hline Tinggi & 1 & 10 & 9 & 90 & 10 & $11,5 \%$ \\
Sedang & 34 & 55,7 & 27 & 44,3 & 61 & $70,1 \%$ \\
Rendah & 6 & 37,5 & 10 & 62,5 & 16 & $18,4 \%$ \\
\hline Total & 41 & 47,1 & 46 & 52,9 & 87 & $100 \%$ \\
\hline
\end{tabular}

Berdasarkan tabel 5 dapat diketahui bahwa ditinjau dari indikator tanggung jawab, sebagian besar atau sebesar $81,6 \%$ responden perawat memiliki tanggung jawab yang tinggi. Indikator ini merupakan indikator motivasi dengan penilaian terbaik. Ditinjau dari indikator prestasi, sebagian besar atau sebesar 64,4\% responden perawat memiliki pretasi kerja yang tinggi. Adapun ditinjau dari indikator prestasi, sebagian besar atau sebesar $78,2 \%$ responden perawat memiliki kemajuan yang sedang.

Tidak adanya perawat yang memiliki motivasi kerja yang rendah pada penelitian ini sesuai dengan syarat profesionalisme caring perawat. Profesionalisme caring perawat ditandai dengan adanya motivasi intrinsik yang tinggi sehingga perawat memiliki komitmen pelayanan serta ketelitian yang tinggi. ${ }^{7}$

\section{Hubungan Pemberian Reward dengan Motivasi Kerja}

Tabel 6.

Hasil Tabulasi Silang Pemberian Reward dengan Motivasi Kerja Perawat di Ruang Rawat Inap JIH Yogyakarta $2015(n=87)$

\begin{tabular}{lllcc}
\hline No & Indikator & & $\mathbf{F}$ & $\%$ \\
\hline 1 & Tanggung jawab & Tinggi & 71 & 81,6 \\
& (Responbility) & Sedang & 16 & 18,4 \\
\hline 2 & Prestasi & Tinggi & 56 & 64,4 \\
& (Achievment) & Sedang & 31 & 35,6 \\
\hline 3 & Kemajuan & Tinggi & 18 & 20,7 \\
& (Advencement) & Sedang & 68 & 78,2 \\
& & Rendah & 1 & 1,1 \\
\hline Total $(\mathrm{n})$ & & 87 & $100 \%$ \\
\hline
\end{tabular}

Hasil tabulasi silang pada tabel 6 menunjukkan bahwa pada kelompok responden yang menilai bahwa pemberian reward adalah tinggi, sebagian besar atau sebesar 90\% memiliki motivasi kerja sedang. Pada kelompok responden yang menilai bahwa pemberian reward adalah sedang, sebagian besar atau sebesar $55,7 \%$ memiliki motivasi kerja tinggi. Adapun pada kelompok yang menilai bahwa pemberian reward adalah rendah, sebagian besar atau sebesar 62,5\% memiliki motivasi kerja sedang.

Tabel 7.

Hasil Uji Korelasi Spearman Rank Pemberian Reward dengan Motivasi Kerja Perawat di Ruang Rawat Inap RS JIH Yogyakarta 2015

\begin{tabular}{ccl}
\hline $\mathbf{r}$ & $\begin{array}{c}\text { Signifikansi } \\
(\mathbf{p})\end{array}$ & Keterangan \\
\hline$-0,083$ & 0,447 & $\begin{array}{l}\text { Tidak ada hubungan } \\
\text { signifikan }\end{array}$ \\
\hline
\end{tabular}

Hasil uji korelasi pada tabel 7 menunjukkan bahwa nilai signifikansi $(p)$ hubungan antara reward dengan motivasi kerja pada perawat di Ruang Rawat Inap RS JIH Yogyakarta 2015 adalah sebesar $0,447(>0,05)$ menunjukkan bahwa tidak ada hubungan yang signifikan antara kedua variabel tersebut. Demikian sehingga pemberian reward tidak berhubungan dengan motivasi kerja perawat di ruang rawat inap Rumah Sakit JIH Yogyakarta.

Hasil ini sesuai dengan hasil penelitian Harumnavamwe dan Kanengoni (2013), dalam studinya juga menemukan bahwa reward berupa uang dan reward bukan berupa uang tidak berhubungan signifikan dengan motivasi kerja. $^{8}$ Amstrong (2007), menjabarkan teori Hezberg dalam teorinya dengan mengatakan bahwa reward merupakan faktor eksternal yang dapat meningkatkan motivasi kerja. Akan tetapi pengujian teori Amstrong (2007) dalam penelitian Langson dan Robbins (2007) membuktikan bahwa hubungan antara reward dengan motivasi tidaklah sederhana karena ada beberapa kondisi yang harus dipenuhi untuk mencapai kondisi di mana reward dapat digunakan sebagai sarana untuk meningkatkan motivasi. Penting bagi individu pekerja tersebut untuk mengetahui bahwa reward yang dia terima adalah 
direct reward bagi performa kinerjanya sehingga terdapat perbedaan reward yang diterima berdasarkan performa kinerja setiap karyawan. Sistem reward semacam ini umumnya berlaku dalam dunia marketing. ${ }^{9}$

Sistem reward eksternal di RS JIH Yogyakarta tidak sesuai dengan sistem reward yang disyaratkan oleh Langson dan Robbins (2007). Perawat menerima reward eksternal/reward material berupa uang dalam jumlah yang sama, termasuk di dalamnya uang jasa pasien yang dibagi dalam jumlah sama rata kepada seluruh perawat dalam satu ruang. Sistem ini menyebabkan tidak ada perbedaan reward yang diterima perawat yang satu dengan yang lainnnya. Demikian sehingga tidak adanya hubungan antara reward dan motivasi pada penelitian ini dikarenakan kondisi sistem reward pada penelitian ini tidak sesuai dengan apa yang disyaratkan oleh Langson dan Robbins (2007). Reward yang sama besarnya menyebabkan perawat tidak terpacu motivasinya karena reward tidaklah bersifat kompetitif.

\section{KESIMPULAN}

Berdasarkan hasil penelitian dan pembahasan hasil penelitian yang telah dipaparkan sebelumnya, maka dapat disimpulkan bahwa:

1. Pemberian reward pada perawat di Ruang Rawat Inap RS JIH Yogyakarta. 2015 adalah berupa reward ekstrinsik (uang dan jaminan sosial) dan berada pada kategori sedang $(70,1 \%)$.

2. Motivasi kerja Perawatdi Ruang Rawat Inap RS JIH Yogyakarta tahun 2015 memiliki motivasi yang sedang (52,9\%).

3. Tidak ada hubungan yang signifikan antara pemberian reward dengan motivasi kerja perawat di Ruang Rawat Inap RS JIH Yogyakarta 2015 (p 0,447) dengan keeratan hubungan sangat rendah $(r-0,083)$.

\section{SARAN}

1. Bagi RS JIH Yogyakarta

Hasil penelitian ini diharapkan dapat menjadi referensi dan bahan kajian bagi manajemen rumah sakit untuk mengambil kebijakan untuk meningkatkan motivasi kerja perawat dalam meningkatkan tanggung jawab, meningkatkan prestasi dan kemajuan dalam bidang pendidikan dan pelatihan (motivasi intrinsik) ataupun dalam mengambil kebijakan terkait sistem pemberian reward ekstrinsik berupa uang dan jaminan sosial.

2. Bagi STIKES Guna Bangsa Yogyakarta

Hasil penelitian ini diharapkan dapat menambahkan referensi dan informasi manajemen keperawatan, untuk Mahasiswa dan Dosen khususnya mengenai hubungan antara pemberian reward dengan motivasi kerja perawat.

\section{DAFTAR PUSTAKA}

Abdurrahmat, F. 2006. Manajemen Sumber Daya Manusia. Jakarta: PT Rineka Cipta.

Rahardjo, S. 2004. Panduan Investasi Reksadana. Jakarta: PT Elex Media Komputindo.

Mangkunegara, A.P. 2009. Evaluasi Kinerja Sumber Daya Manusia. Bandung: Refika Aditama.

Ivancevich, M., Konopaske, J.R, dan Matteson, M.T. 2006. Perilaku dan Manajemen Organisasi. Jakarta: Erlangga.

Wibowo. 2007. Manajemen Kinerja. Jakarta: PT Rajagrafindo Persada.

Suwandono, A., Muharso, A. A., Aryastami, K. 2014. Human Resouces on Health (HRH) for Foreign Countries: A Case of Nurse "Surplus" in Indonesia.Human Resouces Health 5 (1): 1-21.

Morrison, P., Burnard, P. 2010. Caring and Communicating:

Hubungan Interpersonal dalam Keperawatan. Jakarta: EGC

Harunavamwe, M., Kanengoni, $H$. 2013. The Impact of Monetary and Non-Monetary Rewards on Motivation among Lower Level Employees in Selected Retail Shop.African Journal of Business Management 7(38):3929.

Amstrong, M. 2007.Organisation and People Employee Reward. Broadway Wimbledon: CIPD publishers. 